\title{
Chapter 2 \\ Morphology, Ontogeny, Reproduction, and Feeding of True Bugs
}

\author{
Jocélia Grazia, Felipe L. Simões, and Antônio R. Panizzi
}

Abstract In this chapter we present an overview of the morphology, ontogeny, reproduction, and feeding of the 28 higher-level categories (infraorder/superfamily/ family/subfamily) of true bugs occurring in the neotropical region, which are treated in greater detail in Sect. 2.2.

\subsection{Introduction}

The Heteroptera can be diagnosed by the presence of mouthparts typically hemipteran with mandibular stylets concentric and surrounding maxillary stylets. The labium is inserted anteriorly on the head and a distinct gular area is always present, often closed behind to form a buccular bridge. Scent-gland structures are often paired, located and exiting ventrally in the metathoracic pleuron; nymphs with paired scent glands which are placed at the junction of one or more of the following abdominal terga: III/IV, IV/V, V/VI, and VI/VII. A detailed description of the adult morphology of heteropterous insects is found in Schuh and Slater (1995). The eggs may be elongate, cylindrical, curved, or barrel-shaped; they are inserted into a plant tissue, cemented to a substratum, or laid free. A distinct operculum may be present, the same applying to a true egg burster. The cephalic pole of the egg of most bugs bears one or two micropyles or aeromicropyles (apparently with gaseous exchange function). Aero-micropylar processes ornament the egg pole; in all bugs except Cimicoidea, the sperm enters the egg during fertilization through the micropyles. There are ordinarily five nymphal instars, which typically resemble adults and live in similar environments. Aside from the lack of ocelli, wings, and genitalia, nymphs are primarily distinguished by the presence of one

J. Grazia $(\varangle) \cdot$ F.L. Simões

Departamento de Zoologia, Instituto de Biociências,

Universidade Federal do Rio Grande do Sul (UFRGS),

Av. Bento Gonçalves 9500, prédio 43435, Bairro Agronomia,

Porto Alegre, RS 91501-970, Brazil

e-mail: jocelia@ufrgs.br; felipe.lorenz@ufrgs.br

\section{A.R. Panizzi}

Laboratório de Entomologia, Embrapa Trigo, Caixa Postal 3081,

Passo Fundo, RS 99001-970, Brazil

e-mail: antonio.panizzi@embrapa.br 
less tarsal segment than those found in adults. Most heteropterous males apparently deposit sperm in the female in the shape of a spermatophore; the sperm is then stored by the female in the spermatheca. Fertilization and oviposition are simultaneous. Plantfeeding species make up the majority of the Heteroptera. The phytophagous habit has been acquired independently at least twice from predatory precursors over the long millennia in which heteropterans have evolved (Schuh and Slater 1995). Phytophagy is found mostly in the Pentatomomorpha and Cimicomorpha. Considering the heteropteran families, the majority are predaceous upon insects and other arthropods. Some heteropterans have also developed the ability to utilize the blood of vertebrates, a characteristic that has arisen at least three and possibly four times independently in the taxon's evolutionary history.

A brief description of the morphology (item 2), ontogeny and reproduction (item 3), and feeding (item 4) of true bugs is presented. Those issues are discussed in more detail in the chapters of Session II. The taxa are listed in alphabetical order, aiming to make more practical the finding of the information.

\subsection{Morphology}

\subsubsection{Alydidae}

The Alydidae are 8-20 mm long, usually elongate and slender with disproportionately large heads. The broad-headed bugs as they are known are very often myrmecomorphic, particularly as nymphs. Additional diagnostic characters include: bucculae very short; antennae dorsally inserted with segment 1 not constricted at base; ocelli not placed on elevations; corium elongated on costal margin; metathoracic scent-gland auricles well developed; and tibia nonsulcate (Schuh and Slater 1995).

\subsubsection{Anthocoridae}

The anthocorids vary from 1.15 to $5 \mathrm{~mm}$ long, with a porrect head and ocelli always present in macropterous forms. The labium is four segmented (even though it appears to be three segmented), and the labrum is wide and flap-like. The metathoracic scent gland is deeply bilobed behind with a median accessory gland present. The forewing has an elongate median corial groove, with a short ventral fold, which does not reach the cuneus along the costal margin. The hind wing can have or lack a hamus. Both macropterous and brachypterous forms occur. The tibiae have spongy fossae, either well developed or vestigial; foretibiae in males are, in most of genera, armed with a row of teeth or spines in the inner margin; and the tarsi have three segments. The male genitalia are always asymmetrical. The ovipositor is usually developed or sometimes reduced. 


\subsubsection{Aradidae}

The Aradidae are 3-11-mm-long insects mainly diagnosed by the mandibular and maxillary stylets, which are extremely elongate and coiled within, and the absence of ocelli. Their head is of the prognathous type, highly specialized to accommodate the Mycetophagus sucking mouthparts, and the labium is usually short and stout with 4 distinct segments. The wings, when present, are usually dimorphic, well developed, and exceedingly diverse in development and venation. Metathoracic scent glands are well developed, and the canals and evaporating areas vary in shape with striking development. The legs in Aradidae are considerably variable and sometimes modified for stridulation; the trochanters are commonly and usually distinct from the femora; the front tibiae have an apical or periapical comb on the inner side; and the tarsi are bisegmented. In the abdomen stridulatory structures are present in the ventral surface; the connexivum, even lateroventrally, is morphologically a part of the tergum, since the spiracles are considered to mark the lower limit of the tergum. The connexiva of the first segment or the lateral parts of the first tergite are completely lost. The modification of abdominal segments into reproductive systems begins in the seventh segment for females and in the eighth for males.

\subsubsection{Coreidae}

Coreids are usually heavy-bodied insects, elongate or elliptical in shape, ranging from 6 to $40 \mathrm{~mm}$. The head is smaller than the pronotum and the antennae have four segments. Their hind femora may be enlarged, with spines and tubercles, and frequently incrassate, while the hind tibiae are curved, with spines or leaflike expansions; apterous, brachypterous, and macropterous forms occur in the family. Abdominal spiracles ventral; three trichobothria on abdominal segments III-VI, two on segment VII; nymphal dorsal abdominal scent-gland openings between terga $4 / 5$ and $5 / 6$. The genital plates are flattened and the spermatheca has only a proximal pump flange. In several coreid tribes, a pronounced sexual dimorphism occurs in the size and armament of the hind femur (Miller and Emlen 2010).

\subsubsection{Cydnidae}

With ovoid and convex bodies, the cydnids range from 2 to $25 \mathrm{~mm}$. Their head is either quadrate or semicircular, wide, and often explanate; the antennae have five segments. The scutellum never surpasses the middle of the abdomen. The development of wings is variable with the possibility of brachypterous and macropterous forms occurring in the same species; the last three nymphal instars have wing pads, which become more evident in the 5 th. The distal margins of the coxae have a row 
of setae or bristles, known as coxal combs; the tibia has strong and long spines in all extension, and the anterior tibia is usually compressed; and the tarsi have three segments. Female genital plates: Laterotergites 8 fused; gonocoxites 8 large and broad; the spermatheca is relatively small usually with two flanges.

\subsubsection{Dipsocoromorpha}

Of small size (from 1 to $4 \mathrm{~mm}$ ) and often strongly declivous head, the Dipsocoromorpha port antennae are with scape and a short pedicel, flagellomeres long, thin and typically with numerous stout setae; the proepisternum is often inflated. One of the most prominent characteristics of the group is wing morphology. While four wing types are found in the taxon (macropterous, submacropterous, brachypterous, and apterous, some of these occurring concomitantly in the same species), wing morphology is even more complex since the forewing is typically not clearly divided into corium and membrane, ranging from completely membranous to entirely elytrous; the hind wing is often seen with deeply separated lobes. The male genitalia are either symmetrical, with appendage-like laterotergites, or strongly asymmetrical.

\subsubsection{Enicocephalomorpha}

Enicocephalomorpha are small to midsize with body length typically ranging between 2 and $15 \mathrm{~mm}$, are often dull colored, and generally resemble small Reduviidae. Wings are membranous and well developed, but micropterous, brachypterous, and wingless forms, especially in females, also occur (Wygodzinsky and Schmidt 1991). They are characterized by the elongate and porrect head that is subdivided into anterior and postocular lobes by a usually conspicuous postocular constriction (Štys 1995).

\subsubsection{Gerromorpha}

Semiaquatic bugs are rather diversified in general appearance and structurally very diverse (Andersen 1979), which makes morphologically defining the group somewhat difficult (Nieser and Melo 1997). The head of the gerromorphans is typically elongate, with prominent eyes; contrary to the Nepomorpha, the antennae of Gerromorpha are always long and exposed (Heckman 2011); and the rostrum is typically long and slender. The pronotum is a broad plate with a short anterior lobe, while the scutellum is sometimes reduced. The wings in Gerromorpha are very particular, since pterygopolymorphism is common in the infraorder, with some 
species showing continuous variation (Schuh and Slater 1995). The forewings are usually not differentiated into the anterior coriaceous and posterior membranous portions; on the other hand, the hind wings are membranous and shorter but much broader than the forewing. Brachypterous and apterous forms also occur, the latter being more common than macropterous. The scent apparatus of semiaquatic bugs belongs to the "type omphalion" of Carayon (1971), with a single median scent orifice on the metasternum. The legs of Gerromorpha generally have modifications that facilitate movement across the surface of the water, so as to stay over the tension layer, and which can even facilitate copulation. The pretarsi have dorsal and ventral arolia (a synapomorphy of the group); the adult tarsus has three segments, but these can be fused sometimes (Andersen 1982). The abdomen has eight dorsal nonreproductive segments in females and seven in males. Nymphs of semiaquatic bugs differ from adults in their usually softer integument; the metathoracic scent apparatus is not formed until the adult stage.

The male genitalia consist basically of a cylindrical abdominal segment eight, a boat-shaped segment nine (the pygophore), and a lid-shaped segment ten (the proctiger), which covers the posterior end of the pygophore. A relatively simple phallic organ is internally attached to the pygophore, and a pair of parameres arises laterally from it. As for the female genitalia, it is formed by the eighth and ninth abdominal segments. The eighth segment has a basal sclerite or first gonocoxa ventrolaterally on either side, and this sclerite carries ventrally and caudally the first gonapophyses. The second pair of gonocoxae is found on segment nine, to which are attached the second pair of gonapophyses. The male genital segments are often more conspicuous than those of females, which may be concealed.

\subsubsection{Lygaeoidea}

Being the second largest superfamily of Pentatomomorpha, the Lygaeoidea have a plethora of variable morphological characteristics which can hardly be summarized in such a short manner. Nevertheless, the synapomorphies of the taxon can be highlighted: reduced venation nearly always lacking closed cells on the hemelytral membrane and incrassate fore femora found in all basal taxa but lost in a number of distal groups. Also, the Lygaeoidea can be apterous, sub-brachypterous, brachypterous, and macropterous.

\subsubsection{Miridae}

Mirids can stretch from one to more than $15 \mathrm{~mm}$ in ovoid or elongate bodies, although these are variable in adults. The head is triangular and usually prognathous; the eyes are usually large; and the antennae and labium have four segments. Even though most mirids are macropterous, it is common to find submacroptery, 
brachyptery, microptery, and coleoptery. The hemelytra are distinctive, with the corium divided distally into a triangular cuneus and an apical membrane with one or two unequal cells divided by a short longitudinal vein. Trochanters of all legs are divided. The tarsi are most often three segmented. The metathoracic scent glands are paired and the external efferent or evaporative system is usually well developed. The male genitalia are asymmetrical, with a partially membranous endosoma, often inflatable, and confined by a sclerotized phallotheca. The female ovipositor is laciniate; the sperm-storage organ is a large, saclike structure.

\subsubsection{Nabidae}

The Nabidae range from 5 to $15 \mathrm{~mm}$ with elongate or stout bodies. The head is also more or less elongated, with a cylindrical posterior portion; the labium is flexible and usually curving, reaching onto the pro- or mesothorax, with four distinct segments; antennal prepedicellite is present, although variable in length. Being bell shaped, the thorax itself has no particular features; however, wing polymorphism is common in many species, particularly in those living at higher latitudes; depending on the type of prey, legs can either be simple or enlarged and armed with heavy spines, forming a formidable opposable grasping apparatus. Worth noticing on the abdomen is the presence of trichobothria in some taxa. The male genitalia are usually symmetrical, with eventual asymmetrical parameres or phallus; Ekblom's organ is also usually present. In females, a reduced laciniate ovipositor is found in some cases.

\subsubsection{Nepomorpha}

The bodies of the nepomorphans can be ovate and flattened dorsoventrally, globular and rounded, convex on the dorsal surface and straight ventrally, elongated, or elongate-ovoid. Besides the variation of forms and colors, aquatic heteropterans are widely diverse in total body length, with some species measuring a little more than $1 \mathrm{~mm}$ (Pleidae), whereas others are more than $100 \mathrm{~mm}$ long (Belostomatidae). Particularly, the Nepomorpha have reduced antennae (with one to four segments) and a generally small and robust rostrum (three or four segments); the pronotum is long, covering the meso- and metanotum, and the scutellum is always exposed. According to Schuh and Slater (1995), nepomorphans generally have the following six types of wings: micropterous, staphylinid, brachypterous, coleopteroid, submacropterous, and macropterous, although the former five can be grouped into the brachypterous group. The forelegs are generally modified and may be raptorial with the fore femora enlarged or scoop shaped with the fore tarsi unsegmented. The hind legs are generally fringed with golden setae and in some groups can be slightly flattened. The dorsal and ventral arolia are usually present in adults and nymphs 
(Schuh and Slater 1995). Sexual dimorphism is observed in some families: the male genital segments vary from symmetrical to asymmetrical, including modifications, and the female ovipositor is generally not developed.

\subsubsection{Pentatomidae}

The bodies of most pentatomids are of moderate to large size, ranging in length from 4 to $20 \mathrm{~mm}$, and generally ovoid or broadly elliptical. There are, however, some relatively elongate slender species, most of which are associated with grasses. The antennae are usually five segmented, although some species have four. The scutellum is large and usually triangular or subtriangular, in a shield-like form. The forewings are half coriaceous and half membranous, while the hind wings are completely membranous. The tarsi have three segments (two segmented in Cyrtocorinae). Segments VIII, IX, and X of the abdomen are modified into genital structures: whereas the males possess a pygophore with other internal structures like the phallus, ejaculatory reservoir, and spermatheca, females have external plates (laterotergites and gonocoxites) with a generally platelike ovipositor, never truly laciniate.

\subsubsection{Pentatomoid Small Families}

\section{Acanthosomatidae}

Species included in this family resemble median to large pentatomids and may be recognized by the shorter scutellum, two-segmented tarsi, male abdominal segment 8 large and exposed, and most of the females with Pendergrast's organ present.

\section{Canopidae}

Species included in this family are medium-sized $(5-7 \mathrm{~mm})$, almost rounded, dorsally convex and ventrally flat convex and ventrally flat, totally black, and shiny, with purple and green reflexes. The scutellum is enlarged, covering entirely the abdomen and most part of the hemelytra (Grazia et al. 2012).

\section{Dinidoridae}

Adults have large size (10-30 mm), an ovoid and robust body, and a dark brown or black general color, with red/yellow stripes and maculae usually present. The head is carinate laterally, the buccula short and elevated, and the rostrum reaching the meso- and metacoxa. The humeral angles never developed. The scutellum is 
triangular, almost as wide as long, never covering the corium, and the apex usually blunt. Hemelytral membrane venation is reticulate. Dinidor Latreille is the only genus that occurs in the neotropics; it has antennae with five segments and tarsi with three segments.

\section{Megarididae}

Megaridids are small (5 mm or less in length) and coleopteroid in shape. Strongly convex dorsally, the scutellum is enlarged and covering the abdomen and wings. They are dark in color and polished. The anterior margins of the head and pronotum are carinate and the bucculae undeveloped. The antennae are four segmented, with many setae as long as the diameter of segments in females is much longer than in males. The tibia is without spines, and the tarsi are two segmented.

\section{Phloeidae}

Their bodies are depressed; the external margins of juga and pronotum and the base of corium and abdomen broadly foliate. Their eyes are divided into dorsal and ventral portions. Its antenna is three segmented, only partially visible dorsally, and hidden below the expanded juga; segment 1 is very long and segment 3 curved. They have peritreme opening near the lateral margin of the pleuron. Its hemelytral membrane is reticulate. The tarsi are three segmented. The abdominal sterna 3-7 with trichobothria arranged longitudinally to the spiracular line. Spiracle 2 is present and partially exposed.

\section{Tessaratomidae}

Piezosternum Amyot and Serville, the only genus representative of the family in the neotropical region, has worldwide distribution and includes three endemic species to the neotropics. Similar to large pentatomids, tessarotomids can be distinguished from them by its very small head; usually four-segmented antenna; short rostrum; metasternum produced anteriorly, generally into a large bladelike projection reaching the anterior coxae; and pronotum extending over the base of the scutellum.

\subsubsection{Pyrrhocoridae}

As the only known neotropical genus of Pyrrhocoridae, Dysdercus serves as the reference in this section (some of the characteristics may be shared with other pyrrhocorids).

The body length of Dysdercus range from 8 to $18 \mathrm{~mm}$, with an elongate to oval, somewhat flattened, body. The slender and elongated sucking mouthparts reach the 
middle of the thorax and occasionally the abdomen. The pronotum is clearly divided into an anterior third and a posterior two-thirds, these sometimes of different colors. As in other heteropterans, the hind wings are membranous, but the forewings are partly sclerotized and partly membranous, the latter porting two closed cells. The fore femora are, at most, slightly swollen (usually slender), and the metathoracic scent gland lacks an auricle.

Pyrrhocoridae can be distinguished from Largidae most readily by the presence in the females of the latter of a median split on the seventh sternum, indicative of an elongate or laciniate ovipositor; the ovipositor of Pyrrhocoridae is platelike, and the female's seventh sternum is entire.

\subsubsection{Reduviidae}

Most Reduviidae are medium to large bugs and often show elongate or ovoid body shapes. Overall, Reduviidae is one of the most morphologically diverse groups of Heteroptera, ranging from delicate and elongate to large and robust. Reduviidae can also mimic other groups of Heteroptera (Stride 1954), as well as other insects, such as Hymenoptera, with a number of species participating in Müllerian mimicry complexes (Haviland 1931; Hogue 1993). Some of the most distinctive characteristics of the assassin bugs are the necklike shape of the head behind the eyes and the labium, which is short, strongly curved, and inflexible (Schuh and Slater 1995). Other relevant body structures include the membrane of hemelytra, usually with two or three elongated cells; the presence of a fossula spongiosa at the apex of the fore and mid tibiae in many taxa; and the presence of Brindley's glands between the metathorax and the first abdominal segment. The female genitalia have a lateral spermathecae; males with the eighth abdominal segment telescoped largely into the seventh segment and usually with symmetrical genitalia (Schuh and Slater 1995; Weirauch 2008).

\section{Triatominae}

The subfamily is diagnosed, among other features, by the slender and straight labium of its members and their blood-feeding habits (Lent and Wygodzinsky 1979; Clayton 1990; Weirauch 2008). Their general appearance is similar to that of other reduviids. The length of most species varies from 20 to $28 \mathrm{~mm}$, but Dipetalogaster maxima (Uhler) can reach $44 \mathrm{~mm}$ in length, and the smallest species is Alberprosenia goyovargasi (Martínez \& Carcavallo), with $5 \mathrm{~mm}$. The color pattern varies, with an overall black or piceous color and spotted patterns of yellow, brown, orange, or red (Jurberg et al. 2004, 2012, 2013). Opposite to the females, in which the genital plates are simple and extremely homogeneous, the male genital complex of the Triatominae is composed of approximately 15 features, which are highly variable and can be used for generic and specific differentiation (Singh-Pruthi 1925; Dupuis 1955, 1963; Lent and Jurberg 1969, 1975). 


\subsubsection{Rhopalidae}

With a body length ranging from 4 to $15 \mathrm{~mm}$, rhopalids vary greatly in both shape and color. The main characteristics of the head which can be highlighted are the four-segmented antennae, clypeus that surpasses the mandibular plates, and ocelli based on low tubercles. As for the thorax, it is notable that the metathoracic scent-gland openings are commonly, but not always, obsolete or obsolescent, hence the common name "scentless plant bugs"; the corium frequently has large hyaline areas, and the membrane of the forewings always has numerous slender parallel veins arising from a transverse basal vein. Females have inner laterotergites with a platelike ovipositor, whereas the pygophore in males has lateral, median, and paralateral lobes; internally, the spermatheca consists of a round bulb, small pump, and long, generally coiled duct.

\subsubsection{Saldidae}

Most shore bugs are typically small, ranging from 2 to $8 \mathrm{~mm}$, with an ovate body covered by fine setae that repel water and bind layers of air to the body, which indicates that these insects are able to adapt to periods of submergence. Usually, the eyes of the Saldidae are very large, occupying the side of the head that is usually relatively short and broad with visible antennae. All three basic wing forms (apterous, brachypterous, and macropterous) have been recorded for Saldidae (Polhemus and Chapman 1979). Its legs are usually relatively short, slender, or longer; the hind coxae are large, transverse, and broad coxal cavity in the thoracic pleurae and adapted for hopping or jumping; the femora sometimes are armed with spines; and all tarsi are usually three segmented with apical claws. The male genitalia are symmetrical, and the parameres are hook shaped with a distinct processus. In females, the valvulae of the ovipositor are developed or reduced and platelike; also, a spermatheca is present.

\subsubsection{Scutelleridae}

Shield bugs represent a diverse pentatomoid family, which are mainly recognized by the beetle-like appearance, due to the great development of the mesoscutellum (scutellum), which covers almost the entirety of the abdomen. Scutellerids vary greatly in shape, color, and size, but they are usually medium-sized pentatomoids $(10-20 \mathrm{~mm})$. The main thoracic characteristics are the well-developed prosternal keel, weakly sclerotized hemelytra, ostiolar peritreme (which can be present or absent), and usually unarmed legs. The external genitalia are either visible or concealed by sternite VII; thus, most of the diagnostic genital characters (apart from the genital plates) are internal, such as in females with the spermathecal bulb with a simple wall and the genital capsule with a ringlike 8th segment. In males, the phallus often has two or three pairs of well-developed conjunctival projections, and the 
parameres are commonly uncinate (Schuh and Slater 1995; Tsai et al. 2011; Barcellos et al. 2014).

\subsubsection{Thyreocoridae}

Thyreocorids are 3-8-mm-long bugs with oval-elongate, dorsally convex, and ventrally flat bodies, which are characteristically dark colored (usually shiny). The head is declivent and subtriangular in dorsal view, and the antennae are five segmented. The main thoracic features include a strongly convex scutellum, which covers most of the hemelytra, a reduced corium, tibiae with setae, and spines in all their extension and three-segmented tarsi.

\subsubsection{Tingidae}

Tingids range from 2 to $8 \mathrm{~mm}$ and are poorly colored, generally varying in shades of brown. The head is armed with up to nine spines, which can be distributed in variable ways; the antennae have four segments. The pronotum is convex or flat; composed by a collar, a pronotal disk with or without carinae, and a pair of lateral expansions (paranota); and can have a posterior projection covering the scutellum. The collar can be developed, forming a hood, which can fully or partially cover the head. An important morphological characteristic of most tingids is the lacelike network of areolae on the wings, which is very often used in species identification. The male genitalia are symmetrical and the phallus has some sclerotized eversible structures (Lee 1969); the parameres are usually directed backward. The ovipositor is laciniate and the connection between the first valvula and first valvifer is lost, as in Miridae (Schuh and Slater 1995). The spermatheca is absent and the pseudospermatheca is present, but it seems to be unrelated with the sperm-storage function (Marchini et al. 2010).

\subsection{Ontogeny and Reproduction}

\subsubsection{Alydidae}

For the neotropical alydids, not much data is available on their biology, with the exception of a few species with economic interest. Neomegalotomus parvus (Westwood) eggs are laid singly or in groups; on soybean, eggs are laid on the upper third of the plant, preferably on the lower side of leaves, close to the midrib (Panizzi et al. 1996). On pigeon pea, Cajanus cajan (L.) eggs are laid preferably in-between seeds (crevices) of mature pods (Ventura and Panizzi 2000, 2003). Nymphs mimic ants and are darkish. 


\subsubsection{Anthocoridae}

The duration of embryonic development after spawning depends greatly on the temperature, while the total duration of the hatching takes a few minutes. The nymphs do not differ greatly from the adult stage, and growth after hatching has no metamorphosis; it is only driven by shedding or ecdysis. The last one, called fledging, is accompanied by some structural completions, including the full development of the wings (for winged forms) and sexual organs. The normal number of nymphal stages is five, but it is possible that some species evolve in just four steps. The sexual organs are externally invisible except at the fifth instar, where the ovipositor of the female is apparent.

Insemination is done through "traumatic insemination," i.e., injection in the hemocoel or in secondarily developed organs and that is not associated with the genital vias, which are only subsequently reached. The way to oviposit varies according to the different development levels of the ovipositor of the females of the different taxa. Fertilization takes place in the vitellarium, where there are two to seven testes follicles.

\subsubsection{Aradidae}

Aradids generally have one or two generations per year with five nymphal stages: eggs are laid in May, and nymphs hatch in June (the time of incubation depends on temperature and species), reach the fourth instar during the first summer, become adults from July to August, and after which they hibernate. It is not until the following spring that the bugs mate and begin laying eggs.

After copulating (when the male lies beneath the female) in their natural habitats, in fungi, and under tree barks, the eggs are deposited in frass beneath the eggs, and are found partially embedded in softwood in the galleries of termites. A single female can lay $14-45$ eggs.

\subsubsection{Coreidae}

The number of generations per year varies with latitude and as a function of crop cycles, host plant phenology, and host plant specificity. The eggs are cemented to the substrate by the female and laid either in long chains; singly; in small groups, adjacent rows, or large clusters; or even atop one another. Most eggs are laid on host plants, generally on the undersides of leaves, but also along a linear surface or on the backs of males. Five nymphal stadia occur between hatching and adult emergence. Adults live long, reaching more than 50 days (Mitchell 2006). 
Courtship and mating involve antennation, touching with the legs, or other body contact prior to copulation (Eberhard 1998; Tatarnic and Spence 2013; Miller 2011), and males and females may mate multiple times for as long as 6-7 h (McLain et al. 1993; Tatarnic and Spence 2013). Mating often occurs on fruits, and feeding by one or both partners during copulation is common. The most frequent mating position is end to end, with the male facing the opposite direction from the female. Copulatory success appears to correlate with the size of the male (McLain et al. 1993; Tatarnic and Spence 2013).

\subsubsection{Cydnidae}

The females of Cydnidae can lay a single egg underground (García and Bellotti 1980; Riis et al. 2005), egg masses in shallow cracks on the soil surface (Sites and McPherson 1982), or inside the fruits of Ficus (Moraceae) (Mayorga and Cervantes 2001). After that, incubation time can vary from 1 to 4 weeks. Newly hatched nymphs measure from 1.0 to $2.5 \mathrm{~mm}$ in length (García and Bellotti 1980; Sites and McPherson 1982; Riis et al. 2005), and their development also occurs in five instars, and, even though the time spent in these stages is mostly unknown, studies found they can last from 54 to as much as 180 days.

Although little is known about the reproduction of neotropical cydnids, for species that live in the soil, mating occurs in this habitat. During copulation, males and females remain connected by the genitalia and in opposite directions (Willis and Roth 1962). Whereas Cydnidae present solitary behavior, mating occurs in the soil and finding sexual partners is difficult, since the environment where these bugs live restricts large-scale communication between individuals. Like other Heteroptera, it is likely that copulation in Cydnidae is mediated by chemicals and sound signals.

\subsubsection{Dipsocoromorpha}

Not much is known about the development and reproduction of neotropical Dipsocoromorpha, with sparse works mentioning, or dealing with, the five nymphal stages and morphology/coupling of the genitalia.

\subsubsection{Enicocephalomorpha}

Swarming is a biological phenomenon that is rather common in this group and has been documented for species in five genera and both families in the New World (Wygodzinsky and Schmidt 1991). Stys (1981) speculated that all species that are capable of flight might also swarm. Swarms are possibly formed for the purpose of 
mating and are composed of large numbers of males and much smaller numbers of females (Kritsky 1977; Stys 1981). Some enicocephalids have the unusual ability to autotomize, or shed, their wings. This behavior may be related to the cryptic way of life of most species. In females, it could be important when individuals retreat, after swarming and copulation, into the soil, where wings might be a hindrance, similar to wing shedding in termites and ants (Wygodzinsky and Schmidt 1991).

\subsubsection{Gerromorpha}

The eggs of gerromorphan bugs are laid in a wide variety of places, such as on moss and algae, in holes of stones, inserted in plant tissue, on floating objects and living or dead leaves, and many other possibilities. One to 500 eggs can be laid at once or through several days, with incubation periods ranging from 6 to 23 days. Only a few works describing the life cycle of nymphs of neotropical Gerromorpha exist, but it is known that they have four to five instars; the development time takes from 14 to 33 days, during which the two wing pairs start developing before the final molt, where the teneral development takes places, hardening and adding pigmentation to the cuticle, resorption of the now useless muscles, and, in macropterous adults, with the growth of the endoskeleton and flight muscles (Andersen 1982).

The reproductive behavior of semiaquatic bugs has been extensively studied, but the vast majority of the experiments are restricted to temperate species. Four basic mating systems have been described among gerromorphans (Spence and Andersen 1994), but it consists of the male jumping on the back of the female and then engaging in the copulation, usually by attaching its legs to the female's thorax subsequently transferring the sperm in a process that can last as quick as minutes or as long as weeks.

\subsubsection{Lygaeoidea}

As mentioned in the morphology section, lygeoids are a diverse, highly successful group of true bugs and there have been a significant number of important reviews of the habits, life history, and reproduction. For further details on one of the 12 neotropical families of Lygaeoidea, please refer to the respective chapter.

\subsubsection{Miridae}

The life histories of most Miridae, especially tropical ones, are poorly studied or are unknown (Schuh and Slater 1995; Wheeler 2001). Much of what we know about courtship and oviposition behavior, fecundity, longevity, and voltinism is the result 
of studies involving species of agricultural importance. However, it is known that they often have life cycles that last no more than 6 weeks. Firstly, the eggs are inserted, usually, into plant tissue. After eclosion, the transition from the first stage to the final, which can be from three to six (Schuh and Slater 1995; Wheeler 2001), takes $15-30$ days.

Plant bugs are remarkable for their genitalic evolution (Kelton 1959; Cassis and Schuh 2012), including traumatic insemination and sexual antagonistic coevolution (Tatarnic et al. 2006; Tatarnic and Cassis 2010; Cassis and Schuh 2012). Parthenogenesis occurs in a few mirid species, such as the predatory Campyloneura virgula (Herrich-Schaeffer), where males are rare (Wheeler and Henry 1992; Henry 2012).

\subsubsection{Nabidae}

Most details provided in this section are related to Nabis capsiformis (Germar), which is representative of the family (Hormchan et al. 1976), even though some information on other species is also available (however, very little is known about the development of neotropical nabid species).

Generations can be as long lived as 59 days, depending on the conditions provided. After being laid in plant tissue, eggs (more than 110 can be laid) hatch into nymphs after 7-8 days of development. Then, they proceed through the five instars, a process which can last up to 18 days. Adults can live for 21.6 days under laboratory conditions.

Nabidae reproduction is done mainly through vaginal copulation, with fertilization taking place in the mesodermal oviducts near the base of the ovarioles or near the pedicels. The other possibility is through traumatic intravaginal insemination (Carayon 1977).

\subsubsection{Nepomorpha}

Nepomorphan eggs are deposited individually or grouped, submerged or slightly submerged above the water surface, or even distant from the water. They can be deposited over the substrate (plant and algae masses, rocks, logs, and the hemelytra of males) or inside it (usually plant tissues). After eclosion, the nymphs develop across four to five instars, which have a similar lifestyle of the adults. The development time and number of generations are not known for most neotropical species, but in the tropics and/or subtropics, the species or populations can be multivoltine, with three or more generations annually (Saulich and Musolin 2007).

Reproduction in nepomorphans generally takes place in water and includes various methods across the families of the infraorder. Stridulation is quite common in these bugs and plays an important role in mating. The males generally make use of 
different leg pairs to hold the female together for copulation; however, the methods are too variable to be explained in this section (please refer to the Nepomorpha chapter for further details).

\subsubsection{Pentatomidae}

The pentatomid barrel-shaped eggs are laid on the underside of leaves in clusters with tight rows; in early spring, overwintered adult females seek out suitable hosts and typically deposit their eggs on wild host plants. Often, these overwintering populations are found along field borders, particularly along tree lines near their overwintering sites. Later-developing cultivated plants become more attractive when these initial wild hosts dry down, and their proximity allows easy access for stinkbug colonization in crops; emerging nymphs are gregarious and remain on/near the egg mass and then begin to feed and disperse as they grow. Eggs with translucent chorion, through which it is possible to observe their contents, are more common in Pentatomidae than pigmented chorion; the spinose pattern of chorion sculpture seems to be the most frequent, although several studied species show reticulated chorion and a few others a granulated chorion. The number of aero-micropylar processes is rarely used for specific recognition, due to its overlapping in congeneric species; the number varies between 10 and 86 . The number of eggs per mass is relatively constant within Pentatomidae species, related to the number of ovarioles in females and the oviposition strategy of each species. Small egg masses are laid, usually with 14 eggs (Matesco et al. 2007), the number of ovarioles more frequently found in Pentatomidae. Among pentatomids, several life history traits are strongly influenced by temperature, humidity, and food quality. The duration in days of the development from the egg to adulthood is about $48-57$.

\subsubsection{Pentatomoid Small Families}

\section{Acanthosomatidae}

Faúndez (2007a) gives a brief description of the life cycle of $D$. punctiventris, providing details of the mating behavior (Faúndez 2007a; Faúndez et al. 2009). Females lay eggs in clutches, corresponding more or less with the number of ovarioles. Egg and nymphal development time, prereproductive females, and adult longevity have not been studied in any of the neotropical species. Faúndez and Osorio (2010) described maternal care behavior for the neotropical species Sinopla perpunctatus Signoret. The authors also reported coloration change in the female associated to the reproductive period and guard of eggs and nymphs. 


\section{Canopidae}

The biology of the canopids is poorly known.

\section{Dinidoridae}

Eggs or nymphs of any species of the neotropical Dinidoridae have not been formally described up to date. Knowledge is restricted to species from other regions (Malipatil and Kumar 1975; Danielczok and Kocorek 2003). Eggs and nymphs of $D$. mactabilis were illustrated in Schwertner and Grazia (2014). The unique characteristics of the immature include the shape of the eggs and of the aero-micropylar processes, aspect of the chorion surface, and the development of some nymph structures. Eggs are cylindrical, deposited in rows, horizontally positioned to the substrate.

\section{Megarididae}

The general body of nymphs is similar to adults in shape and color; they are heavily sclerotized, with abdominal terga not distinguished; and there is no formal description of eggs.

\section{Phloeidae}

The life cycle of these bugs occurs entirely on the trunks of the host (Salomão et al. 2012). Females protect eggs and early nymphs; the latter attach themselves to the abdomen of the mother (Lent and Jurberg 1965; Guilbert 2003).

\section{Tessaratomidae}

Eggs are spherical, deposited perpendicular to the substrate. The chorion is smooth and thinner than in Dinidoridae. Aero-micropylar processes are reduced, knob-like, and circulating the middle region of the egg, in variable numbers (30-60). The operculum is not apparent, with the line of the operculum dorsolateral extending basally. Nymphs of the 1st, 2nd, and 3rd instars have oval, flattened body; late instars have elongated and more robust body. All species are univoltine and usually use more than one host plant throughout its life cycle (Schaefer et al. 2000; Dzerefos et al. 2009), with biological aspects very similar to Dinidoridae. Depending on the species, females can lay in masses of four rows (3-4-4-3 formula), with an average of 14-28 eggs per clutch. Fertility is considered low (Schaefer et al. 2000). Maternal care has been described for some tessaratomids of the subfamily Oncomerinae in the Australian region (Gogala et al. 1998; Monteith 2006). 


\subsubsection{Pyrrhocoridae}

As mentioned above, Dysdercus serves as the model genus for this section. These bugs' biology and ecology remain poorly known.

\subsubsection{Reduviidae}

Through their mostly platelike ovipositors, reduviids usually glue their eggs to the plant, often in a group, and sometimes cover them a gelatinous material. However, few species are known to guard their eggs. Ground-dwelling species may insert their eggs into the soil, or the eggs may be laid loose. Some reduviines have more well-developed ovipositors, suitable for the insertion of eggs into cracks or crevices.

\section{Triatominae}

Triatominae species are found in almost any habitat offering a degree of climatic stability and access to a blood source. Most of them tolerate a range of air humidity between 30 and $80 \%$, and temperatures of $24-28{ }^{\circ} \mathrm{C}$ are satisfactory. Their development is usually slow at temperatures below $16^{\circ} \mathrm{C}$, whereas temperatures above $40^{\circ} \mathrm{C}$ are lethal. During the rigorous winters of Patagonia, they undergo lethargy, and on strong summers they increase the number of blood meals in order to compensate the higher loss of water. In general, most triatomines are nocturnal, and during the day they remain in their resting places, although they may sometimes go out to suck blood during the day under adverse conditions. In general, the eggs of the majority of triatomine species are deposited free in the environment, although some species have an adhesive substance that makes the eggs stick to the substrate. The triatomines are parasites with slow development, whose life cycle from egg to adult includes five nymphal stages, ranging from 3 to 4 months in Rhodnius prolixus up to 2 years in Panstrongylus megistus. This life span can vary considerably according to the temperature to which the bugs are submitted. The first information on copulation in triatomines was published by Neiva (1914), who noted that Panstrongylus megistus females appeared to copulate only once, maintaining the eggs fertile throughout their life span. Courting is not complex in this group of insects, and copulation in some species has been observed in the laboratory by some authors. Prior to copulation, the male approaches the female, attempting to immobilize her with the three legs on one side of the body in a dorsolateral position (Abalos and Wygodzinsky 1951; Hack and Bar 1979; Lent and Wygodzinsky 1979; Lima et al. 1986; Rojas et al. 1990; Manrique and Lazzari 1994). 


\subsubsection{Rhopalidae}

Since detailed studies of eggs and oviposition have not been made for most neotropical rhopalids, this section is based mainly in temperate and subtropical congeners and conspecifics. Rhopalids typically lay their eggs on or near host plants, more specifically on sepals, nearby stems, leaf midribs, floral pappi, the undersides of leaves, and flower pedicels, but they can also be buried in the soil or simply dropped to the ground; while as many as 1,000 eggs can be laid by a single female (Wheeler 1977), they require about 8 days to hatch over an average monthlong oviposition period (Yonke and Walker 1970a, b). As with the eggs, not much is known about neotropical rhopalid nymphs, but the relative genera from other regions have a mature period through the five instars that ranges from 22 to 40 days (Yonke and Walker 1970a, b; Paskewitz and McPherson 1983). Adult males have been reported to live for as long as the average life span of 86,6 days, while females lived for up to 47,7 days.

Mostly, what is known of the reproduction of rhopalids focuses on the consequences of low food availability to reproductive life span and diapause; however, this is not the main focus of this section. Apart from that, Carroll $(1988,1991)$ reported two different mating systems: promiscuous mating, when females are abundant, and a guarding system when males are much more abundant than females.

\subsubsection{Saldidae}

Even though the life cycles of Saldidae are not yet completely understood, some generalizations can be made. The eggs are laid in over the vegetation or other substrates. Their maturation requires approximately 1 week, and the hatched nymphs will develop across the five instars in around 2-3 weeks (Wiley 1922; Jordan and Wendt 1938). There are some cold-adapted species and others that can overwinter in the egg or adult stages (Wroblewski 1966).

Saldidae usually copulate side by side (Polhemus and Chapman 1979), and according to Cobben (1957) the female's forewing and male abdominal segments show some modifications to facilitate this copulatory position.

\subsubsection{Scutelleridae}

Even though the length of life cycles in Scutelleridae is quite variable, some model studies do exist, where total cycles lasted for as long as 60 days. Scutellerid eggs are laid in two or more rows, on several parts of a host plant. These egg masses vary in number, averaging from 14 to almost a hundred eggs (around 75-92); the incubation time is not very well known, but a 7-day period has been recorded for one 
species (Paleari 1992). After eclosion, the nymphs proceed through five instars until reaching the adult stage.

\subsubsection{Thyreocoridae}

The life cycle of the Thyreocoridae generally corresponds to that of the Pentatomidae (Grazia and Schwertner 2008). They can be uni-, bi-, or multivoltine: in low latitudes, a higher number of generations per year occur, whereas in higher latitudes only one generation per year is possible (McPherson 1972; Lung and Goeden 1982; Bundy and McPherson 1997, 2009). Eggs are laid singly and glued laterally to the substrate, often in the host plants' reproductive parts and less frequently in branches or leaves; the development varies between 8 and 11 days. After eclosion, the first instar nymphs are active, differing from the nymphs of other Pentatomoidea families, feeding and not showing gregarious behavior; the subsequent development through the five nymphal stages takes from 30 to 45 days.

Not much can be said about the reproduction of thyreocorids, but a pre-copulatory behavior has been described by Bundy and McPherson (1997), and it consists on the male standing behind the female and starting the contact through antennation. After the female's acceptance, the copulation takes place with the individuals positioned in opposite directions, just touching genitalic structures; this process can last for hours.

\subsubsection{Tingidae}

In general, tingid eggs have been relatively poorly studied; thus, not much is known about their egg development. However, some studies delved into the oviposition sites and strategies. Generally, there are one or two generations per year (univoltine or bivoltine), although multivoltine species are known (Neal and Douglas 1990). Oviposition sites are variable, as species drop their eggs on roots, stems, bud flowers, and/or leafs. The eggs can be inserted on the spongy mesophyll, partially inserted in the vegetal tissue (pseudo-endophytic oviposition), or placed at the surface of the vegetal tissue (exophytic oviposition). They are usually oviposited in the abaxial surface of the leaf and can be arranged in small or big groups, or they can be isolated. Although most species have five nymphal instars, four-instar cycles have already been reported (Johnson 1936). Apart from that, tingid nymphs have yet to be further explored, since only recently they started to be featured in the specialized literature (e.g., Guilbert and Montemayor 2010; Guidoti and Barcellos 2013; Montemayor 2009; Montemayor and Dellapé 2010; Montemayor et al. 2011), and their function and evolution were just studied in a few occasions (Guilbert 2004; Scholze 1992).

As with the life cycle, the reproductive behavior of the Tingidae has been seldom explored, with no courtship behavior reported. 


\subsection{Feeding}

\subsubsection{Alydidae}

The alydids are phytophagous, feeding on noncultivated and cultivated legumes, solanaceas, and other plant families. Research work on their biology, particularly on their life history in nature, to reveal their association with host plants either cultivated or not is needed.

\subsubsection{Anthocoridae}

Anthocoridae are chiefly predaceous bugs that occur in a variety of habitats where they feed on different arthropods, including mites and insects. Other examples of food source not so often found in Anthocoridae are plants (forbs, shrubs, and trees), ants, and litter.

Nymphal food does not differ substantially from that of adults. The young Anthocoridae, after hatching, are voracious predators of small arthropods and they attack the same prey as that of imagos, preferring only individuals proportional to their size (eggs, young larvae). The number of prey consumed can reach or exceed several hundred mites or a hundred aphids during the nymphal development of a single individual. It seems at least one meal is needed between two molts, and the most hearty meal precedes the ecdysis. Growth is sometimes compatible with a not predatory feeding habitus (Péricart 1972).

\subsubsection{Aradidae}

Most aradid species are subcortical and mycetophagous, mainly feeding on the bark of dead trees and fungi juices. They are mostly found on branches that have died recently and are not totally dessicated. When the tree becomes too dry, they apparently abandon it for another branch. They have elongated maxillary and mandibular stylets that are coiled within the head; in the resting position, both stylets are coiled up to form a compact double spiral (Weber 1930), and when the bug is feeding, the length of the uncoiled stylets may reach as much as five to six times that of the insect. Nymphs are found with the adults and feed from the same sources.

\subsubsection{Coreidae}

Coreids are phytophagous, feeding on gymnosperms and angiosperms, through the phloem, buds, fruits, developing seeds, and mature seeds (Mitchell 2000); no coreids feed exclusively from xylem, but hydration from xylem occurs. Opportunistic 
feeding on fecal matter, carrion, and insect eggs has been reported (Adler and Wheeler 1984; Menezes-Netto et al. 2012) but is never the primary source of nutrients. Plant preference spans a wide spectrum from specialization on a single genus to extreme polyphagy. Nymphs of the first instar often remain in the vicinity of the egg mass and appear to need only a source of water for successful molt to the second stadium (Cook and Neal 1999). Probing into plant tissue may occur, but the tissue selected is always vegetative (tendrils, leaves, terminal buds) (Rodrigues et al. 2007; Wheeler and Miller 1990). The second through fifth instars require a nutrient source and feed similarly to the adults in most cases, although the shorter stylets may prevent access to deeper plant tissues.

\subsubsection{Cydnidae}

Cydnid nymphs are typically polyphagous and likely feed on plants closer to the site of hatching. Feeding of host plants through suction, for both nymphs and adults, includes roots, ground pods, aboveground structures, fallen seeds, and fruits. Plants of several families have been reported as hosts (Timonin 1958; Becker 1967; Riis et al. 2005; Mayorga and Cervantes 2001; Chapin et al. 2006), ranging from small-sized plants, such as A. hypogea, to larger-sized ones, such as Eucalyptus spp. Very often these insects are reported as agricultural pests and, depending on the population level, the symptoms of their occurrence can be checked on the shoots, whose leaves turn yellow and dry (Gallo et al. 2002; Riis et al. 2005; Oliveira and Malaguido 2004; Pereira et al. 2012).

\subsubsection{Dipsocoromorpha}

Given the small size and cryptic habits of most Dipsocoromorpha, direct observations of their biology are limited. However, it is known that they can feed on chironomid larvae (Esaki and Miyamoto 1959), Collembola, mites, and other Dipsocoromorpha.

\subsubsection{Enicocephalomorpha}

Enicocephalids are predaceous and appear to feed on soft-bodied insects and other arthropods, but few direct observations are available. In captivity, they were fed with larvae and freshly killed adult flies, symphylids (Symphyla), and campodeids (Diplura), as well as ant larvae and pupae. 


\subsubsection{Gerromorpha}

In general, semiaquatic bugs are intermediate opportunistic stage predators (polyphagous carnivores and scavengers) in the food chains of their communities, normally attacking small invertebrates that fall on the water surface and become trapped or those who swim up to it (Menke 1979). Many species of Gerromorpha are also known to be cannibalistic, feeding upon weaker individuals of their own kind (Butler 1923; Sprague 1956; Andersen 1982). The main sources of food for nymphs and adults are dead or half-dead midges, mosquito larvae and pupae, ostracods, cladocerans, ephemeropterans, and collembolans, while the adults can also feed on pelagic cnidarians, sea anemones, planktonic crustaceans, and fish larvae.

As mentioned above, cannibalism is very common in the infraorder, to the point where some (if not most) experiments with live cultures can be completely lost due to this behavior.

\subsubsection{Lygaeoidea}

Most lygaeids feed on seeds or plant sap, whereas only a few are predatory. They have piercing-sucking mouthparts, which are made up of the mandibles and maxillae modified to form needlelike stylets lying within a grooved labium (Schuh and Slater 1995). Feeding methods can be divided into two "types": "stylet-sheath" feeders and "lacerate-flush" feeders (Schuh and Slater 1995; Sweet 2000). The majority of Lygaeoidea are lacerate-flush feeders, a method commonly used by species that feed on portions of the plant rich in nutrients, such as seeds (Schuh and Slater 1995), whereas the families Blissidae, Malcidae, and Colobathristidae are predominantly sap feeders. The lygaeids are often related as pests of agriculture crops (Sweet 2000).

Specific food sources and modified strategies for the neotropical families can be found in the Lygaeoidea chapter in this book.

\subsubsection{Miridae}

Most plant bugs are oligophagous, occurring on members of one plant family or on plants belonging to a few closely related families (Wheeler 2000), but their piercingsucking mouthparts and the presence of powerful salivary secretions also allow access to different nutrient resources, such as dried carrion and feces (Wheeler 2001). Even though mirids are often not recognized as predators, specially due to the lack of specialized morphological characteristics for preying, plant bugs are frequently causing severe injuries in crops and have recently invaded several areas across the world due to changes in agricultural practices that lead to the increase of the host range of many plant bugs (Wheeler 2001). 


\subsubsection{Nabidae}

The nabids are usually described as pests of cotton or other important agroecosystems. However, they can get their nutrients from other insects as well. Unfortunately, there's not much information on their feeding sources.

\subsubsection{Nepomorpha}

Both nymphs and adults are predaceous. They feed on crustaceans, dipteran larvae, and other insects, sometimes even on small vertebrates, such as fishes, tadpoles, salamander and freshwater snakes (Menke 1963), but usually on matter found in deposits on the bottom of the pool and upon the dead leaves that have lodged in its shallow waters, such as diatoms, desmids, Oscillatoria, and spores of various algae. Cannibalism is sometimes observed in the taxon, specially from starved individuals feeding on nymphs.

\subsubsection{Pentatomidae}

The majority of the Pentatomidae is herbivorous, but members of one subfamily (Asopinae) are predaceous on other insects. Both adults and nymphs of plantfeeding species may damage plants, mostly by piercing the plant tissues and thus opening a path for pathogens to enter the plant. Independent of the food source, most species are generalists.

\subsubsection{Pentatomoid Small Families}

\section{Acanthosomatidae}

All known acanthosomatids are phytophagous, usually recorded in more than one host, which includes trees and shrubs (Kumar 1974; Schaefer and Ahmad 1987; Faúndez 2007b, 2009). The feeding sites of acanthosomatids include the young tissues of the host and reproductive parts (Schaefer and Ahmad 1987; Faúndez 2007b, c). Casual records of feeding on decaying organic matter and predation including cannibalism (Miller 1971) are known, probably related to the shortage of suitable host plants (Schaefer and Ahmad 1987). Polyphagy seems to be the rule, but specializations can occur at different levels (Schaefer and Ahmad 1987; Faúndez 2007c, 2009). For instance, Sinopla perpunctatus is registered only in Nothofagus spp. in Chile and is considered a specialized species (Faúndez 2007c; Osorio 2009). Otherwise, Acrophyma cumingii (Westwood) and Ditomotarsus punctiventris Spinola are considered generalists (Faúndez 2007a, 2009). 


\section{Canopidae}

Nymphs and adults of Canopus spp. were registered on fungi (McHugh 1994).

\section{Dinidoridae}

All species studied so far are exclusively phytophagous, feeding both in reproductive and vegetative parts of their hosts. The data indicate that polyphagy is widespread, but monophagy in some species is likely. Some species may exhibit gregarious behavior during a part of the year, being found in large quantities together on the host, i.e., Dinidor mactabilis which was recorded in Smilax japecanga Grisebach (Smilacaceae) in southern Brazil (Grazia et al. 2012).

\section{Megarididae}

The biology and ecology of the megaridids are completely ignored; it is accepted that all species are exclusively phytophagous.

\section{Phloeidae}

The unique cryptic morphology of the phloeids makes these bugs to be confused with the bark of trees where they live (Lent and Jurberg 1965; Grazia et al. 2012). Nymphs and adults feed on the vascular system of the hosts (Bernardes et al. 2005).

\section{Tessaratomidae}

All species studied so far are exclusively phytophagous, feeding on both reproductive and vegetative parts of their host. Polyphagy seems to be the rule, but as for Dinidoridae, some species may show host preference [e.g., Musgraveia sulciventris (Stål) feeds primarily on plants of the family Rutaceae and is considered pest in the Australian region] (Schaefer and Ahmad 1987; Schaefer et al. 2000).

\subsubsection{Pyrrhocoridae}

Pyrrhocoridae often feed on the ripening seeds, or secretions on the seeds, of common, fairly low plants (mostly members of the order Malvales). Since they basically feed on a restricted number of sources, some genera or species can be of economic importance, like Dysdercus that become serious pests of cotton. Other food sources include wheat, water and energy from the nectar of various flowers and from probing fruits (Myers 1927; Van Doesburg 1966), and even other insects (Schouteden 
1912; Kamble 1971). Citrus seems to be such a favored plant (Moizant and Téran 1970, Riley \& Howard in Myers 1927), but it may only reflect the likelihood that citrus groves often lay near cotton fields.

\subsubsection{Reduviidae}

As the common name implies, the assassin bugs are strictly predaceous. Although many Reduviidae appear to feed on a wide variety of arthropods, they sometimes show prey preferences or even prey specializations (see summary in Hwang and Weirauch 2012). Some of these preferences include millipedes (Cachan 1952; Forthman and Weirauch 2012), termite predators (McMahan 1983), ants (Jacobson 1911), spiders (Wignall and Taylor 2008; Jackson et al. 2010), and other reduviids (Bérenger and Pluot-Sigwalt 2009).

\section{Triatominae}

Triatomine bugs are obligatory hematophagous insects in all stages of their development and in both sexes, requiring numerous blood meals to complete their development. The amount of blood ingested varies according to the species as well as in relation to the life stage, and generally the 4th and 5 th instar nymphs are the ones that feed the most. The vast majority of species feed on the blood of mammals or birds, but some can feed on reptile or amphibian blood (Carcavallo et al. 1998/1999). Coprophagy (ingestion of feces), kleptohematophagy (sucking blood already ingested by another triatomine), and hemolymphagy (sucking hemolymph from other arthropods) have also been reported by various authors (Lafont 1912; Brumpt 1914; Lent and Martins 1940; Wood 1941; Ryckman 1951; Sandoval et al. 2000). Resistance to long periods of fasting and the fact that many species are generalists favor their survival in nature.

\subsubsection{Rhopalidae}

The rhopalids are exclusively plant-feeding bugs, which specialize on particular host plant taxa as food resources, mainly herbs and woody plants. However, even specialists may take water or nutriment from other sources, including flowers, sweet fruits, and dead insects, which may sometimes lead to confusion about the definitive host on which they depend for growth and reproduction. Usually, Rhopalidae are found hosting on the seeds of plants of the family Sapindaceae. Often, groups of nymphs are found feeding on a single seed, forming a cluster around the seed; feeding on seeds of sapindaceous canopy and light gap lianas in aggregations may exceed a million individuals in number (Carroll and Loye 1987; Wolda and Tanaka 1987). Only some genera, like Boisea, have been reported as nuisance pests (e.g., Schowalter 1986). 


\subsubsection{Saldidae}

Most members of Saldidae are predaceous, feeding on small insects (Brooks and Kelton 1967), mainly Diptera larvae, other saldids (Wroblewski 1966), and even their own eggs (Rimes 1951). Some species can adapt to scavenger or carnivore habits (Merritt et al. 2008). After catching the prey, the rostrum is inserted and proteases enzyme are injected to immobilize and liquefy the body contents before they can be sucked up as in several other predaceous Heteroptera (Picado 1937, 1939; Cheng 1967; Pereira and Melo 1998).

\subsubsection{Scutelleridae}

Scutellerids are generally considered to be exclusively phytophagous, although some authors consider these bugs generalists (Javahery et al. 2000), with extreme examples, such as when some were found feeding on a decomposing snake (Chérot et al. 1998) and on putrefied fish carrion baits (Eger, personal observation). Stems, leaves, and flowers may be used as food although fruit and seeds seem to be most commonly used. Despite their mostly polyphagous habit, several species have been reported to prefer plants from the family Euphorbiaceae. Other known host plant families include Malvaceae and Lamiaceae. The first instar nymphs do not feed, while the other instars feed on the very same plants where their eggs were deposited.

\subsubsection{Thyreocoridae}

Being exclusively herbivorous, thyreocorids are generally associated to bushes, feeding and living in the reproductive parts of the host plants. Even though most species are restricted to one or two plants (Biehler and McPherson 1982; Bundy and McPherson 1997), up to ten different plant families hosting a single species have been recorded.

\subsubsection{Tingidae}

These exclusively phytophagous bugs are usually found on the undersides of leaves (with some exceptions), where they feed on the sap of living plants by piercing the epidermis with their very slender stylets. These stylets are protrusile and retractile, and can easily penetrate the cellular tissue to extract the sap. Their feeding activities may cause great injury and plasmolysis of the foliage. Many cultivated and wild plants of prime importance in agriculture and horticulture are seriously affected by 
the feeding activities of these insects (Drake and Ruhoff 1965). Some nonneotropical genera have been reported to induce galls and feed on pollen and moss (Péricart 1983).

\subsection{Concluding Remarks}

Morphological studies on the neotropical Heteroptera are increasing in the last four decades specially for the groups with economic interest. Considering the neotropical fauna, the knowledge of the ontogeny, reproduction, and feeding is still incipient.

\section{References}

Abalos JW, Wygodzinsky P (1951) Las Triatominae Argentinas (Reduviidae, Hemiptera). Publ Inst Med Reg 601:1-179

Adler PH, Wheeler AG Jr (1984) Extra-phytophagous food source of Hemiptera-Heteroptera: bird droppings, dung, and carrion. J Kans Entomol Soc 57:21-27

Andersen NM (1979) Phylogenetic inference as applied to the study of evolutionary diversification of semiaquatic bugs (Hemiptera: Gerromorpha). Syst Zool 28:554-578

Andersen NM (1982) The semiaquatic bugs (Hemiptera, Gerromorpha). Phylogeny, adaptations, biogeography and classification. Entomonograph 3:1-455

Barcellos A, Eger J Jr, Grazia J (2014) Scutelleridae. In: Roig-Juñent S, Claps LE, Morrone JJ (eds) Biodiversidad de Artrópodos Argentinos, vol 3. Sociedad Entomologica Argentina, Mendoza (in press)

Becker M (1967) Estudos sobre a família Scaptocorinae na região neotropical (Hemiptera: Cydnidae). Arq Zool 15:291-325

Bérenger J-M, Pluot-Sigwalt D (2009) Notes sur Micrauchenus lineola (Fabricius 1787), espèce termitophile et termitophage (Heteroptera: Reduviidae: Harpactorinae, Apiomerini). Ann Soc Entomol Fr (n s) 45:129-133

Bernardes JL, Grazia J, Barcellos A, Salomão AT (2005) Descrição dos estágios imaturos e notas sobre a biologia de Phloea subquadrata (Heteroptera, Phloeidae). Iheringia Sér Zool 95:415-420

Biehler JA, McPherson JE (1982) Life history and laboratory rearing of Galgupha ovalis (Hemiptera: Corimelaenidae), with descriptions of immature stages. Ann Entomol Soc Am 75:465-470

Brooks AR, Kelton LA (1967) Aquatic and semiaquatic Heteroptera of Alberta, Saskatchewan and Manitoba (Hemiptera). Mem Ent Soc Can 51:3-92

Brumpt E (1914) Importance du cannibalisme et coprophagie chez les Réduvidés hématophàges (Rhodnius et Triatoma) pour la conservation des trypanosomas pathogenes en dehors de l'hote vertebré. Bull Soc Pathol Exot 7:702-705

Bundy CS, McPherson JE (1997) Life history and laboratory rearing of Corimelaena obscura (Heteroptera: Thyreocoridae) with descriptions of immature stages. Ann Entomol Soc Am 90:20-27

Bundy CS, McPherson JE (2009) Life history and laboratory rearing of Corimelaena incognita (Hemiptera: Heteroptera: Thyreocoridae), with descriptions of immature stages. Ann Entomol Soc Am 102:1068-1076

Butler EA (1923) A biology of British Hemiptera-Heteroptera. Witherby, London 
Cachan P (1952) Etude de la prédation chez les Réduvides de la région Éthiopienne. 1. La prédation en groupe chez Ectrichodia gigas H-Sch. Phys Comp Oecol 2:378-385

Carayon J (1971) Notes et documents sur l'appareil odorant métathoracique des hémiptères. Ann Soc Entomol Fr (N S) 7:737-770

Carayon J (1977) Insémination extra génitale traumatique. In: Grassé PP (ed) Traité de Zoologie, Anatomie, Systématique, Biologie, T. VIII, fasc. V-A. Masson, pp 351-390

Carcavallo RU, Galíndez-Girón I, Jurberg J, Lent H (eds) (1998/1999) Atlas of Chagas disease vectors in the Americas. Editora Fiocruz, Rio de Janeiro

Carroll SP (1988) Contrasts in reproductive ecology between temperate and tropical populations of Jadera haematoloma, a mate-guarding hemipteran (Rhopalidae). Ann Entomol Soc Am 81:54-63

Carroll SP (1991) The adaptive significance of mate guarding in the soapberry bug, Jadera haematoloma (Hemiptera: Rhopalidae). J Insect Behav 4:509-530

Carroll SP, Loye JE (1987) Specialization of Jadera (Hemiptera: Rhopalidae) on the seeds of Sapindaceae (Sapindales), and coevolutionary responses of defense and attack. Ann Entomol Soc Am 80:373-378

Cassis G, Schuh RT (2012) Systematics, biodiversity, biogeography, and host associations of the Miridae (Insecta: Hemiptera: Heteroptera: Cimicomorpha). Annu Rev Entomol 57:377-404

Chapin JW, Sanders TH, Dean LO, Hendrix KW, Thomas JS (2006) Effect of feeding by a burrower bug, Pangaeus bilineatus (Say) (Heteroptera: Cydnidae), on peanut flavor and oil quality. J Entomol Sci 41:33-39

Cheng L (1967) Studies on the biology of Gerridae (Hem., Heteroptera). I: Observations on the feeding of Limnogonus fossarum (F.). Entomol Mon Mag 102:121-129

Chérot F, Pauwels OSG, Eger JE, Chimsunchart C (1998) Unusual feeding behavior in a scutellerid: a case of scavenging on snake. Nat Hist Bull Siam Soc 46:207-208

Clayton RA (1990) A phylogenetic analysis of the Reduviidae (Hemiptera: Heteroptera) with redescription of the subfamilies and tribes. Doctor thesis, The George Washington University, Washington, DC, USA

Cobben RH (1957) Beitrag zur Kenntnis der Uferwanzen (Hem. Het. Fam. Saldidae). Ent Berichten $17: 245-257$

Cook CA, Neal JJ (1999) Feeding behavior of larvae of Anasa tristis (Heteroptera: Coreidae) on pumpkin and cucumber. Environ Entomol 28:173-177

Danielczok T, Kocorek A (2003) External morphology of four African species of Coridius Ill. (Heteroptera: Pentatomoidea: Dinidoridae). Pol J Entomol 72:63-73

Drake CJ, Ruhoff FA (1965) Lacebugs of the world: a catalog (Hemiptera: Tingidae). US Nat Mus Bull 243:1-634

Dupuis C (1955) Les genitalia des Hemipteres. Mem Mus Nat Hist Nat Ser A Zool 6:183-278

Dupuis C (1963) Progrés récents de l'étude des genitalia des Hétéroptères (etude bibliographique critique). Doctor thesis, Museum National d'Histoire Naturelle

Dzerefos CM, Witkowski ETF, Toms R (2009) Life-history traits of the edible stinkbug, Encosternum delegorguei (Hem., Tessaratomidae), a traditional food in southern Africa. J Appl Entomol 133:749-759

Eberhard WG (1998) Sexual behavior of Acanthocephala declivis guatemalana (Hemiptera: Coreidae) and the allometric scaling of their modified hind legs. Ann Entomol Soc Am 91:863-871

Esaki T, Miyamoto S (1959) A new or little known Hypselosoma from Amami-Oshima and Japan, with the proposal of a new tribe for the genus (Hemiptera). Sieboldia 2:109-120

Faúndez EI (2007a) Lista de las especies de Acanthosomatidae (Insecta: Hemiptera) de la región de Magallanes (Chile). An Ins Patagonia 35:75-78

Faúndez EI (2007b) Notes on the biology of Ditomotarsus punctiventris Spinola, 1852 (Hemiptera: Acanthosomatidae) in the Magellan region, and comments about the crypsis in Acanthosomatidae. An Ins Patagonia 35:67-70 
Faúndez EI (2007c) Asociación críptica entre Sinopla perpunctatus Signoret, 1863 (Acanthosomatidae: Hemiptera) y el Nirre Nothofagus antarctica (G. Forster) Oersted (Fagaceae) en la Región de Magallanes (Chile). Bol Soc Entomol Aragonesa 40:563-564

Faúndez EI (2009) Contribution to the knowledge of the genus Acrophyma Bergroth, 1917 (Hemiptera: Heteroptera: Acanthosomatidae). Zootaxa 2137:57-65

Faúndez EI, Osorio GA (2010) Contribution to the knowledge of Cylindrocnema plana Mayr, 1864 (Hemiptera: Heteroptera: Acanthosomatidae). An Ins Patagonia 38:159-161

Faúndez EI, Osorio GA, Bahamondez CP, Monsalve EA (2009) Comportamiento gregario en los hábitos sexuales de Ditomotarsus punctiventris Spinola, 1852 (Hemiptera: Heteroptera: Acanthosomatidae). Bol Biodiversidad Chile 1:15-18

Forthman M, Weirauch C (2012) Toxic associations: a review of the predatory behaviors of millipede assassin bugs (Hemiptera: Reduviidae: Ectrichodiinae). Eur J Entomol 109:147-153

Gallo D, Nakano O, Silveira-Neto S, Carvalho RPL, Baptista GC, Berti Fo E, Parra JRP, Zucchi RA, Alves SB, Vendramim JD, Marchini LC, Lopes JRS, Omoto C (2002) Entomologia agrícola. Fealq, Piracicaba

García CA, Bellotti AC (1980) Estudio preliminar de la biología y morfología de Cyrtomenus bergi $\mathrm{F}$. Nueva plaga de la yuca. Rev Colomb Entomol 6:55-61

Gogala M, Yong H-S, Brühl C (1998) Maternal care in Pygoplatys bugs (Heteroptera: Tessaratomidae). Eur J Entomol 95:311-315

Grazia J, Cavicchioli RR, Wolff VRS, Fernandes JAM, Takiya DM (2012) Hemiptera. In: Rafael JA, Melo GAR, Carvalho CJB, Casari S (eds) Os insetos do Brasil: Diversidade e taxonomia. Editora Holos, Ribeirão Preto, pp 348-405

Guidoti M, Barcellos A (2013) On the nymphs of lantana lace bug Teleonemia scrupulosa Stål (Hemiptera: Heteroptera: Tingidae: Tinginae): ontogenetic features of integumentary structures highlighted. Zootaxa 3613:289-296

Guilbert É (2003) Habitat use and maternal care of Phloea subquadrata (Hemiptera: Phloeidae) in the Brazilian Atlantic forest (Espirito Santo). Eur J Entomol 100:61-63

Guilbert É (2004) Do larvae evolve the same way as adults in Tingidae (Insecta: Heteroptera)? Cladistics 20:139-150

Guilbert É, Montemayor SI (2010) Tingidae (Insecta, Heteroptera) from the Argentinan Yungas: new records and descriptions of selected fifth instars. Zoosystema 32:549-565

Hack WH, Bar ME (1979) Comportamento sexual de Triatoma infestans en laboratório. Facena 3:105-117

Haviland MD (1931) The Reduviidae of Kartabo Bartica District, British Guiana. Zoologica $7: 129-154$

Heckman CW (2011) Encyclopedia of South American aquatic insects: Hemiptera - Heteroptera. Illustrated keys to known families, genera, and species in South America. Springer, New York

Henry TJ (2012) First eastern North American records of Campyloneura virgula (Hemiptera: Heteroptera: Miridae: Bryocorinae). Proc Entomol Soc Wash 114:159-163

Hogue CL (1993) Latin American insects and entomology. University of California Press, Berkeley Hormchan P, Schuster MF, Hepner LW (1976) Biology of Tropiconabis capsiformis. Ann Ent Soc Am 69:1016-1018

Hwang WS, Weirauch C (2012) Evolutionary history of assassin bugs: insights from divergence dating and ancestral state reconstruction. PLoS ONE 7:e45523

Jackson RR, Salm K, Nelson XJ (2010) Specialized prey selection behavior of two East African assassin bugs, Scipinnia repax and Nagusta sp. that prey on social jumping spiders. J Insect Sci 10(82):1-19

Jacobson E (1911) Biological notes on the hemipteron Ptilocerus ochraceus. Tijdschr Ent 54:175-179

Javahery M, Schaefer CW, Lattin JD (2000) Shield bugs (Scutelleridae). In: Schaefer CW, Panizzi AR (eds) Heteroptera of economic importance. CRC Press, Boca Raton, pp 475-503

Johnson CG (1936) The biology of Leptobyrsa rhododendri Horvath (Hemiptera, Tingitidae), the Rhododendron lacebug. 1. Introduction, bionomics and life history. Ann Appl Biol 23:342-368 
Jordan KHC, Wendt A (1938) Zur Biologie von Salda litoralis L. (Hem. Het.). Stettiner Ent Zeitng 99:273-292

Jurberg J, Galvão C, Noireau F, Carcavallo RU, Rocha DS, Lent H (2004) Uma Iconografia dos Triatomíneos. Entomol Vect 11:457-494

Jurberg J, Galvão C, Rocha DS, Dale C, Cunha V (2012) Vetores da doença de Chagas no Brasil. Instituto Oswaldo Cruz, Rio de Janeiro

Jurberg J, Cunha V, Cailleaux S, Raigorodschi R, Lima MS, Rocha DS, Moreira FFF (2013) Triatoma pintodiasi sp. nov. do subcomplexo T. rubrovaria (Hemiptera, Reduviidae, Triatominae). Rev Pan-Amaz Saúde 4:43-56

Kamble ST (1971) Bionomics of Dysdercus koenigii Fabr. (Hemiptera: Pyrrhocoridae). J NY Entomol Soc 79:154-157

Kelton LA (1959) Male genitalia as taxonomic characters in the Miridae (Hemiptera). Can Entomol Suppl 11:1-72

Kritsky G (1977) Observations on the morphology and behavior of the Enicocephalidae (Hemiptera). Entomol News 88:105-110

Kumar R (1974) A revision of world Acanthosomatidae (Heteroptera: Pentatomidae). Key to and description of subfamilies, tribes and genera, with designation of types. Aust J Zool Supl Ser 34:1-60

Lafont A (1912) Trypanosomide d'un reduvide (Conorhenus rubrofasciatus) inoculable au rat et à la sourris. Ann Inst Pasteur 26:893-922

Lee CE (1969) Morphological and phylogenic studies on the larvae and male genitalia of the East Asiatic Tingidae (Heteroptera). J Fac Agric 15:138-256

Lent H, Jurberg J (1965) Contribuição ao conhecimento dos Phloeidae Dallas, 1851, com um estudo sôbre genitália (Hemiptera, Pentatomoidea). Rev Bras Biol 25:123-144

Lent H, Jurberg J (1969) O gênero Rhodnius Stål, 1859 com um estudo sobre a genitália das espécies (Hemiptera, Reduviidae, Triat.). Rev Bras Biol 29:487-560

Lent H, Jurberg J (1975) O gênero Panstrongylus Berg, 1879 com um estudo sobre a genitália externa das espécies (Hemiptera, Reduviidae, Triatominae). Rev Bras Biol 35:379-438

Lent H, Martins AV (1940) Estudo sobre os Triatomideos do Estado de Minas Gerais com descrição de uma espécie nova. Rev Entomol 11:877-886

Lent H, Wygodzinsky P (1979) Revision of Triatominae (Hemiptera, Reduviidae) and their significance as vectors of Chagas disease. Bull Am Mus Nat Hist 163:123-529

Lima MM, Jurberg P, Almeida JR (1986) Behavior of triatomines (Hemiptera: Reduviidae) vectors of Chagas disease. I. Courtship and copulation of Panstrongylus megistus (Burm., 1835) in the laboratory. Mem Inst Oswaldo Cruz 81:1-5

Lung KYH, Goeden RD (1982) Biology of Corimelaena extensa on tree tobacco, Nicotiana glauca. Ann Entomol Soc Am 75:177-180

Malipatil MB, Kumar R (1975) Biology and immature stages of some Queensland Pentatomomorpha (Hemiptera: Heteroptera). J Aust Entomol Soc 14:113-128

Manrique G, Lazzari CR (1994) Sexual behaviour and stridulation during mating in Triatoma infestans (Hemiptera: Reduviidae). Mem Inst Oswaldo Cruz 89:629-633

Marchini D, Del-Bene G, Dallai R (2010) Functional morphology of the female reproductive apparatus of Stephanitis pyrioides (Heteroptera, Tingidae): a novel role for the pseudospermathecae. J Morphol 271:473-482

Matesco VC, Grazia J, Campos LA (2007) Description of new genus and species of Ochlerini from Central America (Hemiptera: Pentatomidae: Discocephalinae). Zootaxa 1565:63-68

Mayorga MC, Cervantes PL (2001) Life cycle and description of a new species of Amnestus Dallas (Hemiptera-Heteroptera: Cydnidae) associated with the fruit of several species of Ficus (Moraceae) in Mexico. J NY Entomol Soc 109:392-402

McHugh JV (1994) On the natural history of Canopidae (Heteroptera: Pentatomoidea). J NY Entomol Soc 102:112-114

McLain DK, Burnette LB, Deeds DA (1993) Within season variation in the intensity of sexual selection on body size in the bug Margus obscurator (Hemiptera Coreidae). Ethol Ecol Evol $5: 75-86$ 
McMahan EA (1983) Adaptations, feeding preferences, and biometrics of a termite-baiting assassin bug (Hemiptera: Reduviidae). Ann Entomol Soc Am 76:483-486

McPherson JE (1972) Life history of Corimelaena lateralis lateralis (Hemiptera: Thyreocoridae) with descriptions of immature stages and list of other species of Scutelleroidea found with it on wild carrot. Ann Entomol Soc Am 65:906-911

Menezes-Netto AC, Varella AC, Fernandes OA (2012) Maize-dwelling insects omnivory in Spodoptera frugiperda (J.E. Smith) (Lepidoptera: Noctuidae) egg masses. Braz Arch Biol Technol 55:97-100

Menke AS (1963) A review of the genus Lethocerus in North and Central America, including the West Indies (Hemiptera: Belostomatidae). Ann Entomol Soc Am 56:261-267

Menke AS (1979) The semiaquatic and aquatic Hemiptera of California (Heteroptera: Hemiptera). Bull Calif Insect Surv 21:1-166

Merritt RW, Cummins KW, Berg MB (2008) Aquatic insects of North America. Kendall/Hunt Publ. Co., Dubuque

Miller CW (2011) The heliconia bug, Leptoscelis tricolor. Featured creatures. http://entnemdept. ufl.edu/creatures/misc/bugs/heliconia_bug.htm

Miller CW, Emlen DJ (2010) Across and within population differences in the size and scaling relationship of a sexually-selected trait in Leptoscelis tricolor (Hemiptera: Coreidae). Ann Entomol Soc Am 103:209-215

Miller NCE (1971) The biology of the Heteroptera, 2nd edn. E.W. Classey Ltd., Hampton

Mitchell PL (2000) Leaf-footed bugs. In: Schaefer CW, Panizzi AR (eds) Heteroptera of economic importance. CRC Press, Boca Raton, pp 337-403

Mitchell PL (2006) Polyphagy in true bugs: a case study of Leptoglossus phyllopus (L.) (Hemiptera, Heteroptera, Coreidae). Denisia 19:1117-1134

Moizant RC, Téran JB (1970) Dysdercus maurus Distant (Hemiptera, Pyrrhocoridae) sobre Citrus spp. Agron Trop (Maracay) 20:267-269

Monteith GB (2006) Maternal care in Australian oncomerine shield bugs (Insecta, Heteroptera, Tessaratomidae). Denisia 19:1135-1152

Montemayor SI (2009) Description of a new Corythucha from Argentina (Hemiptera: Heteroptera: Tingidae), with description of its life cycle. Zootaxa 2170:61-68

Montemayor SI, Dellapé PM (2010) On the identity of Gargaphia subpilosa Berg, 1879, G. bergi Monte, 1940 and G. penningtoni Drake, 1928 (Insecta, Hemiptera, Heteroptera, Tingidae), with the description of immatures of G. bergi. Zoosystema 32:155-162

Montemayor SI, González-Herrera A, Villalobos K (2011) Description of a new Pleseobyrsa (Heteroptera: Tingidae) from Costa Rica. Rev Mex Biodiversidad 82:475-480

Myers JG (1927) Ethological observations on some Pyrrhocoridae of Cuba (HemipteraHeteroptera). Ann Entomol Soc Am 20:279-300

Neal JW Jr, Douglas LW (1990) Seasonal dynamics and the effect of temperature in Corythucha cydoniae (Heteroptera: Tingidae). Environ Entomol 19:1299-1304

Neiva A (1914) Revisão do gênero Triatoma Lap. Doctor thesis, Faculdade de Medicina, Rio de Janeiro, Brasil

Nieser N, Melo AL (1997) Os heterópteros aquáticos de Minas Gerais: guia introdutório com chave de identificação para as espécie de Nepomorpha e Gerromorpha. Editora UFMG, Belo Horizonte

Oliveira LJ, Malaguido AB (2004) Flutuação populacional dos percevejos castanhos da raiz, Scaptocoris castanea Perty (Hemiptera: Cydnidae), no perfil do solo em áreas produtoras de soja nas regiões centro-oeste e sudeste do Brasil. Neotrop Entomol 33:283-291

Osorio GA (2009) Primer registro para la región del Maule de Sinopla perpunctatus Signoret, 1864 (Hemiptera: Heteroptera: Acanthosomatidae). Bol Biodiversidad Chile 1:35-37

Paleari LM (1992) Biologia de Agonosoma flavolineata Laporte, 1832 (Hemiptera, Scutelleridae). Rev Bras Entomol 36:521-526

Panizzi AR, Hirose E, Oliveira EDM (1996) Egg allocation by Megalotomus parvus (Westwood) (Heteroptera: Alydidae) on soybean. An Soc Entomol Bras 25:537-543 
Paskewitz SM, McPherson JE (1983) Life history and laboratory rearing of Arhyssus lateralis (Hemiptera: Rhopalidae) with descriptions of immature stages. Ann Entomol Soc Am $76: 477-482$

Pereira MH, Melo AL (1998) Influência do tipo de presa no desenvolvimento e na preferência alimentar de Belostoma anurum (Herrich-Schaffer, 1848) e B. plebejum (Stal, 1858) (Heteroptera, Belostomatidae). Oecol Bras 5:41-49

Pereira MF, Peres RM, Borges RS (2012) Population of Scaptocoris castanea Perty (Hemiptera: Cydnidae) in a crop-livestock integration system. Neotrop Entomol 41:409-413

Péricart J (1972) Anthocoridae, Cimicidae et Microphysidae de l'Ouest- Paléarctique. 7. Hemiptera. In: Masson (ed) Fauna de l'Europe et du Bassin Méditerranéen. Paris

Péricart J (1983) Hémiptères Tingidae Euro-Méditerranéens. Faune Fr 69:1-620

Picado TC (1937) Estudo experimental sobre o veneno de Lethocerus delpontei (De Carlo) (Hemiptera-Belostomidae). Mem Inst Butantan 10:305-310

Picado TC (1939) Étude experimentale du venin de Lethocerus delpontei (De Carlo). Trav Stn Zool Wimereux 13:533-562

Polhemus JT, Chapman HC (1979) Family Saldidae/shore bugs. In: Menke AS (ed) The semiaquatic and aquatic Hemiptera of California (Heteroptera: Hemiptera), Bulletin of the California insect survey 21. University of California Press, Berkeley, pp 16-33

Riis L, Belotti AC, Arias B (2005) Bionomics and population growth statistics of Cyrtomenus bergi (Hemiptera: Cydnidae) on different host plants. Fla Entomol 88:1-10

Rimes GD (1951) Some new and little-known shore-bugs (Heteroptera-Saldidae) from the Australian region. Trans R Soc S Aust 74:135-145

Rodrigues D, Sampaio DS, Isaias RMDS, Moreira GRP (2007) Xylem and seed feeding by two passion vine leaffooted bugs, Holymenia clavigera and Anisoscelis foliacea marginella (Hemiptera: Coreidae: Anisoscelini), with notes on mouthpart morphology. Ann Entomol Soc Am 100:907-913

Rojas JC, Malo EA, Gutierrez-Martínez A (1990) Mating behavior of Triatoma mazzottii Usinger (Hemiptera: Reduviidae) under laboratory conditions. Ann Entomol Soc Am 83:598-602

Ryckman RE (1951) Recent observations of cannibalism in Triatoma (Hemiptera, Reduviidae). J Parasitol 37:43-437

Salomão AT, Postali TC, Vasconcellos-Neto J (2012) Bichos-cascas na Serra do Japi: história natural dos percevejos Phloeidae (Hemiptera). In: Vasconcellos-Neto J, Polli PR, Penteado-Dias AM (eds) Novos olhares, novos saberes sobre a Serra do Japi: ecos de sua biodiversidade. Editora CRV, Curitiba, pp 321-337

Sandoval CM, Joya M, Gutierrez R, Angulo VM (2000) Cleptohaemathophagia of the triatome bug Belminus herreri. Med Vet Entomol 14:100-101

Saulich AH, Musolin DL (2007) Seasonal development of aquatic and semiaquatic true bugs (Heteroptera). St. Petersburg University Press, St. Petersburg (in Russian, with extended 6p English Summary). ISBN 978-5-288-04332-1

Schaefer CW, Ahmad I (1987) The food plants of four pentatomoid families (Hemiptera: Acanthosomatidae, Tessaratomidae, Urostylidae, and Dinidoridae). Phytophaga 1:21-34

Schaefer CW, Panizzi AR, James DG (2000) Several small pentatomoid families (Cyrtocoridae, Dinidoridae, Eurostylidae, Plataspidae, and Tessaratomidae). In: Schaefer CW, Panizzi AR (eds) Heteroptera of economic importance. CRC Press, Boca Raton, pp 505-512

Scholze W (1992) Sekretschwitzen_ bei Netzwanzenlarven: Zur Morphologie, Chemie und biologischen Bedeutung von Integumentbildungen mit sekretorischer Funktion bei Netzwanzenlarven (Heteroptera, Tingidae). Inaugural-dissertation zur Erlangung des Doktorgrades der Fakultät Biologie, Chemie und Geowissenschaften. Universität Bayreuth, Bayreuth

Schouteden H (1912) Les hémiptères parasites des cotonniers en Afrique. Rev Zool Africaine $1: 297-321$

Schowalter TD (1986) Overwintering aggregation of Boisea rubrolineatus (Heteroptera: Rhopalidae) in western Oregon. Environ Entomol 15:1055-1056 
Schuh RT, Slater JA (1995) True bugs of the world (Hemiptera: Heteroptera): classification and natural history. Cornell University Press, Ithaca

Schwertner CF, Grazia J (2014) Dinidoridae, Megarididae y Tessaratomidae. In: Roig-Juñent S, Claps LE, Morrone JJ (eds) Biodiversidad de artrópodos Argentinos, vol 3. Sociedad Entomologica Argentina, Mendoza (in press)

Singh-Pruthi H (1925) The morphology of the male genitalia in Rhynchota. Trans R Entomol Soc $1: 127-267$

Sites RW, McPherson JE (1982) Life history and laboratory rearing of Sehirus cinctus cinctus (Hemiptera: Cydnidae), with descriptions of immature stages. Ann Entomol Soc Am $75: 210-215$

Spence JR, Andersen NM (1994) Biology of water striders: interactions between systematics and ecology. Annu Rev Entomol 39:101-128

Sprague IB (1956) The biology and morphology of Hydrometra martini Kirkaldy. Univ Kans Sci Bull 38:579-693

Stride GO (1954) On the specific status of Phonoctonus subimpictus Stål. Rev Zool Bot Afr $50: 13-16$

Štys P (1981) Unusual sex ratios in swarming and light-attracted Enicocephalidae (Heteroptera). Acta Entomol Bohemoslov 78:430-432

Štys P (1995) Dipsocoromorpha. In: Schuh RT, Slater JA (eds) True bugs of the world (Hemiptera: Heteroptera): classification and natural history. Comstock Publishing Associates, Cornell University Press, Ithaca, pp 67-73

Sweet MH II (2000) Seed and chinch bugs (Lygaeoidea). In: Schaefer CW, Panizzi AR (eds) Heteroptera of economic importance. CRC Press, Boca Raton, pp 143-264

Tatarnic NJ, Cassis G (2010) Sexual coevolution in the traumatically inseminating plant bug genus Coridromius. J Evol Biol 23:1321-1326

Tatarnic NJ, Spence JR (2013) Courtship and mating in the crusader bug Mictis profana (Fabricius). Aust J Entomol 52:151-155

Tatarnic NJ, Cassis G, Hochuli DF (2006) Traumatic insemination in the plant bug genus Coridromius Signoret (Heteroptera: Miridae). Biol Lett 2:58-61

Timonin MI (1958) Scaptocoris talpa Champ. on the roots of banana and other plants. Plant Prot Bull FAO 6:1-2

Tsai J-F, Rédei D, Yeh GF, Yang MM (2011) Jewel bugs of Taiwan (Heteroptera: Scutelleridae). National Chung Hsing University, Taichung

Van Doesburg PH Jr (1966) Heteroptera of Suriname: I. Largidae and Pyrrhocoridae. Stud Fauna Suriname Guyanas 9:1-60

Ventura MU, Panizzi AR (2000) Oviposition behavior of Neomegalotomus parvus (West.) (Hemiptera: Alydidae): daily rhythm and site choice. An Soc Entomol Bras 29:391-400

Ventura MU, Panizzi AR (2003) Population dynamics, gregarious behavior and oviposition preference of Neomegalotomus parvus (Westwood) (Hemiptera: Heteroptera: Alydidae). Braz Arch Biol Technol 46:33-39

Weber H (1930) Biologie der Hemipteren. Biologische Studienbücher, XI. J. Springer, Berlin

Weirauch C (2008) Cladistic analysis of Reduviidae (Heteroptera: Cimicomorpha) based on morphological characters. Syst Ent 33:229-274

Wheeler AG (1977) Life history of Niesthrea louisianica (Hemiptera: Rhopalidae) on rose of Sharon in North Carolina. Ann Entomol Soc Am 70:631-634

Wheeler AG (2000) Plant bugs (Miridae) as plant pests. In: Schaefer CW, Panizzi AR (eds) Heteroptera of economic importance. CRC Press, Boca Raton, pp 37-83

Wheeler AG (2001) Biology of the plant bugs (Hemiptera: Miridae). Pests, predators, opportunists. Cornell University Press, Ithaca

Wheeler AG, Henry TJ (1992) A synthesis of the Holarctic Miridae (Heteroptera): distribution, biology, and origin, with emphasis on North America. Thomas Say Foundation, Entomological Society of America, Lanham 
Wheeler AG Jr, Miller GL (1990) Leptoglossus fulvicornis (Heteroptera: Coreidae), a specialist on magnolia fruits: seasonal history, habits, and descriptions of immature stages. Ann Entomol Soc Am 83:753-765

Wignall AE, Taylor PW (2008) Biology and life history of the araneophagic assassin bug Stenolemus bituberus including a morphometric analysis of the instars (Heteroptera, Reduviidae). J Nat Hist 42:59-76

Wiley GO (1922) Life history notes on two species of Saldidae (Heteroptera) found in Kansas. Kans Univ Sci Bull 14:301-311

Willis ER, Roth LM (1962) Soil and moisture relations of Scaptocoris divergens Froeschner (Hemiptera: Cydnidae). Ann Entomol Soc Am 55:21-33

Wolda H, Tanaka S (1987) Dormancy and aggregation in a tropical insect Jadera obscura (Hemiptera: Rhopalidae). Proc Koninklijke Nederlandse Akademie van Wetenschappen Ser C Biol Med Sci 90:351-356

Wood SF (1941) Notes on the distribution and habits of reduviid vectors of Chagas'disease in the Southwestern United States. Pan-Pac Entomol 17:85-94

Wroblewski A (1966) Shorebugs (Heteroptera, Saldidae) of Poland. Polskie Pismo Ent 36:219-302

Wygodzinsky PW, Schmidt K (1991) Revision of the New World Enicocephalomorpha (Heteroptera). Bull Am Mus Nat Hist 200:1-265

Yonke TR, Walker DL (1970a) Field history, parasites, and biology of Harmostes reflexulus (Say) (Hemiptera: Rhopalidae). J Kans Entomol Soc 4:444-450

Yonke TR, Walker DL (1970b) Description of the egg and nymphs of Harmostes reflexulus (Hemiptera: Rhopalidae). Ann Entomol Soc Am 63:1749-1754 